\title{
Body length of female Macrosetella gracilis (Copepoda: Harpacticoida) from various depth zones in the Red Sea
}

\author{
Ruth Böttger-Schnack
}

Institut für Meereskunde an der Universität Kiel, Düsternbrooker Weg 20, D-2300 Kiel, Federal Republic of Germany

\begin{abstract}
Body length of female Macrosetella gracilis was analysed at different depths, in various regions and during 2 seasons in 1980-81 in the Red Sea. Two distinct size groups, $>1.2 \mathrm{~mm}$ and $<1.2 \mathrm{~mm}$, were present. A literature review suggests that the smaller size group (mode length $\mathrm{ca}$ $1.1 \mathrm{~mm}$ ) is restricted mainly to the Red Sea. Possible causes for the formation of $M$. gracilis size morphs are discussed.
\end{abstract}

\section{INTRODUCTION}

The pelagic harpacticoid copepod Macrosetella gracilis Dana, 1848 has a worldwide distribution in tropical and subtropical seas. It is known to associate with the pelagic bluegreen algae Oscillatoria (Trichodesmium) spp. (Borstad \& Borstad 1977, Carpenter 1983). The algal filaments serve as food for the adult copepods (Roman 1978) and provide a substrate for the non-pelagic developmental stages (Björnberg 1965). Quantitative data on the population structure and vertical distribution of $M$. gracilis in pelagic areas are however scarce. Due to the long, thin body form, even adults cannot be sampled quantitatively in the commonly used $0.3 \mathrm{~mm}$ mesh nets (Böttger 1985, Böttger-Schnack \& Schnack 1989 [companion article]).

Recent investigations in the central and northern Red Sea, conducted with $0.1 \mathrm{~mm}$ mesh nets, revealed the existence of several distinct surface and deep water populations of Macrosetella gracilis in this area (BöttgerSchnack \& Schnack 1989). The occurrence of 2 arbitrarily separated size groups of females, $<1.2 \mathrm{~mm}$ and $>1.2 \mathrm{~mm}$ in length, differed considerably both regionally and at various depths. The observations led to the question of whether the different size distributions resulted from a more or less continuous transition from smaller to larger M. gracilis females, or whether distinct size groups can be identified. The present paper describes the results of a detailed length analysis, employing narrower size classes, on $M$. gracilis females taken from selected samples from the epipelagic, mesopelagic and bathypelagic zones

\section{MATERIAL AND METHODS}

Zooplankton samples were collected from the RV 'Valdivia' at permanent stations in the Red Sea: in the northern Red Sea, above the Kebrit Deep $\left(24^{\circ} 44^{\prime} \mathrm{N}, 36^{\circ} 15^{\prime} \mathrm{E}\right)$ between 9 and 15 October 1980 , and in the central Red Sea, above the Atlantis II Deep $\left(21^{\circ} 23^{\prime} \mathrm{N}, 38^{\circ} 04^{\prime} \mathrm{E}\right)$ between 15 October and 8 November 1980 and from 21 to 24 February 1981. A station map and details of the sampling programme are given by Böttger-Schnack \& Schnack (1989). A multiple opening-closing net system (Weikert \& John 1981) equipped with five $0.1 \mathrm{~mm}$ mesh nets was towed vertically from $450 \mathrm{~m}$ to the surface and usually took samples at $50 \mathrm{~m}$ intervals. In autumn 1980, additional samples were taken in the Atlantis II Deep area to a depth of $1650 \mathrm{~m}$. Intervals of $150 \mathrm{~m}$ were sampled between $450 \mathrm{~m}$ and $1050 \mathrm{~m}$, and $200 \mathrm{~m}$ intervals between $1050 \mathrm{~m}$ and $1650 \mathrm{~m}$. Plankton samples were fixed in a $4 \%$ formaldehyde-seawater solution buffered with hexamethylene tetramine, and transferred into a formaldehyde-free preservative containing $5 \%$ propylene glycol $0.5 \%$ propylene phenoxetol, and $94.5 \%$ filtered seawater (Steedman 1976) after ca 2 yr of fixation.

Length frequency of female Macrosetella gracilis was analysed at all 3 permanent stations using about 50 to 100 individuals each from the epipelagic zone $(0$ to 
$50 \mathrm{~m}$ ) and from midwater depths, 250 to $450 \mathrm{~m}$. In the central Red Sea during autumn 2 samples of females were analysed from below $450 \mathrm{~m}$, one from 600 to $750 \mathrm{~m}$ and the other from 1450 to $1650 \mathrm{~m}$. In order to demonstrate a possible dependence of the length of females on the abundance of the blue-green algae Trichodesmium spp., 3 surface samples taken at 1 wh intervals were analysed at the central station during autumn. The density of algal filaments was different on each occasion as follows: (A) 4 filaments $1^{-1}$, (B) 70 filaments $\mathrm{l}^{-1}$ and $(\mathrm{C})$ a 650 filaments $\mathrm{l}^{-1}$ bloom. The length frequency of deep-dwelling females from below $250 \mathrm{~m}$ was determined from samples in those depth layers where maximum densities of females occurred: 400 to $450 \mathrm{~m}$ at the northern station, 350 to $400 \mathrm{~m}$ at the central station during winter, and 300 to $350 \mathrm{~m}$ and 250 to $300 \mathrm{~m}$ at the central station during autumn.

Length was measured under a stereomicroscope to the nearest $0.01 \mathrm{~mm}$ at a magnification of $40 \times$. It was taken from the tip of the prosome to the end of the caudal rami, excluding the extremely long furcal setae. Most individuals were slightly bent due to fixation. Therefore, each specimen was placed laterally between 2 movable cover slips in a small droplet of lactophenol, which softened the exoskeleton. By carefully moving the cover slips together, the specimens were straightened, and their total length could be measured.

\section{RESULTS}

Fig. 1 shows the length-frequency distribution of female Macrosetella gracilis in the Atlantis II Deep area during autumn 1980. Two separate size categories of the females were established. The length of the smaller females ranged between $0.98 \mathrm{~mm}$ and $1.25 \mathrm{~mm}$ (mode 1.1 to $1.2 \mathrm{~mm}$ ). Larger females measured between 1.25 and $1.6 \mathrm{~mm}$ in length (mode 1.35 to $1.4 \mathrm{~mm}$ ). Both size groups were present in the surface zone as well as in midwater layers in varying proportions. At the surface, large $M$. gracilis females were most abundant during the Trichodesmium bloom (Fig. 1C). In midwater layers, however, high numbers of large females occurred during times of both low and high amounts of bluegreen algae at the surface (Fig. 1A, C).

Below $450 \mathrm{~m}$, the proportion of Macrosetella gracilis females in the larger size group decreased with depth (Fig. 2). In the deepest stratum sampled (1450 to $1650 \mathrm{~m}$ ) all $M$. gracilis females were in the smaller size group. Their mode length was $1.1 . \mathrm{mm}$.

Three months later, in February 1981, the same 2 size groups were still present in the area of the Atlantis II Deep (Fig. 3). Larger females, with a mode length of $1.35 \mathrm{~mm}$, were congregated at midwater depths, whereas the smaller females were present both near the surface and in midwater zones. The size of the females at this station was measured at a lower magnification $(25 \times)$ than in autumn $(40 \times)$, so the size classes in Fig. 3 are broader $(0.02 \mathrm{~mm})$ than in Fig. 1 $(0.01 \mathrm{~mm})$.

In the Kebrit Deep area, 2 vertically separated populations of Macrosetella gracilis were present during autumn 1980 . One was near the surface $(0$ to $50 \mathrm{~m})$ and the other inhabited midwater depths between 350 and $450 \mathrm{~m}$ (Böttger-Schnack \& Schnack 1989). Three sam-
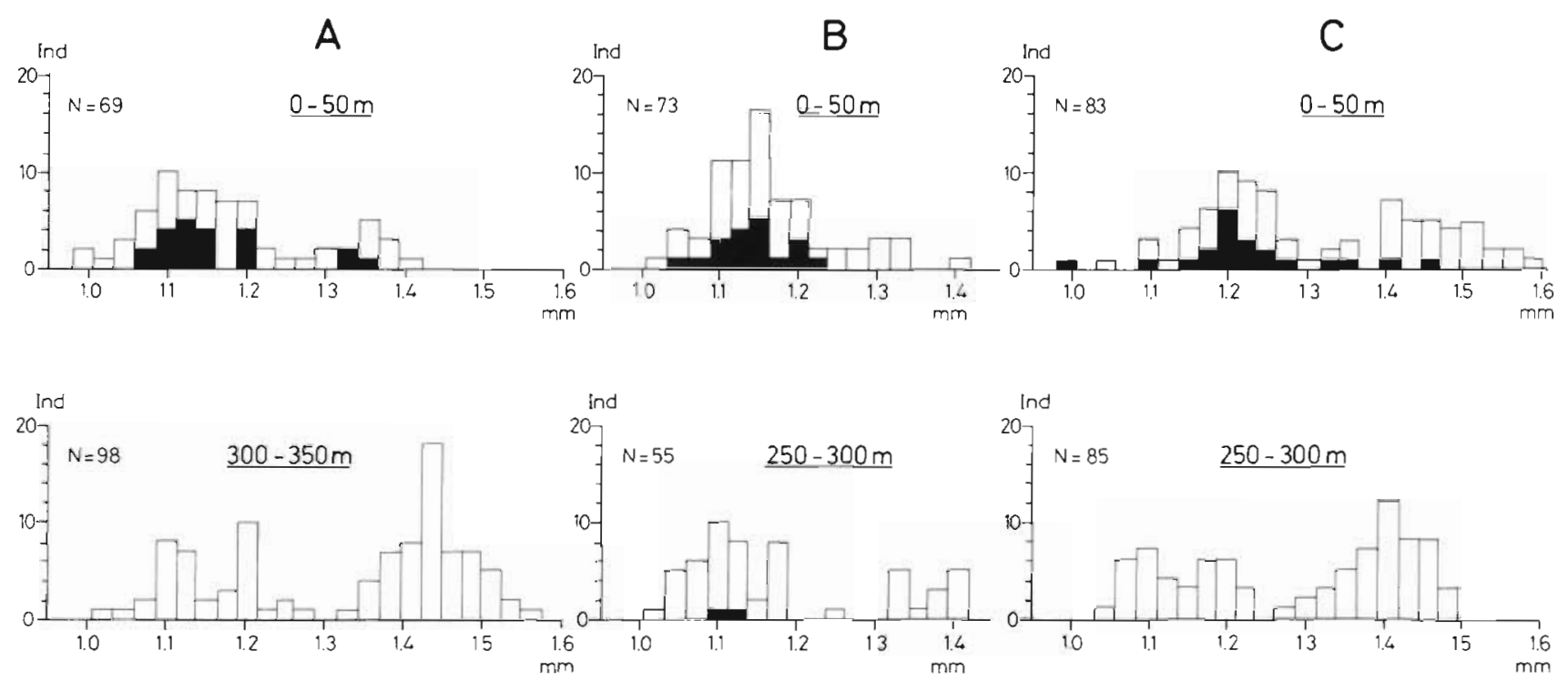

Fig. 1. Macrosetella gracilis. Length-frequency distribution of females from the epipelagic (0 to $50 \mathrm{~m}$ ) and upper mesopelagic (250 to $350 \mathrm{~m}$ ) zones of the Atlantis II Deep, October and November 1980. Prevailing densities of Trichodesmium spp. are rated as follows: $\mathrm{A}=4$ filaments $\mathrm{l}^{-1}, \mathrm{~B}=70$ filaments $\mathrm{l}^{-1}, \mathrm{C}=650$ filaments $\mathrm{l}^{-1}$ Lengths of egg-bearing females are shown by solid columns 

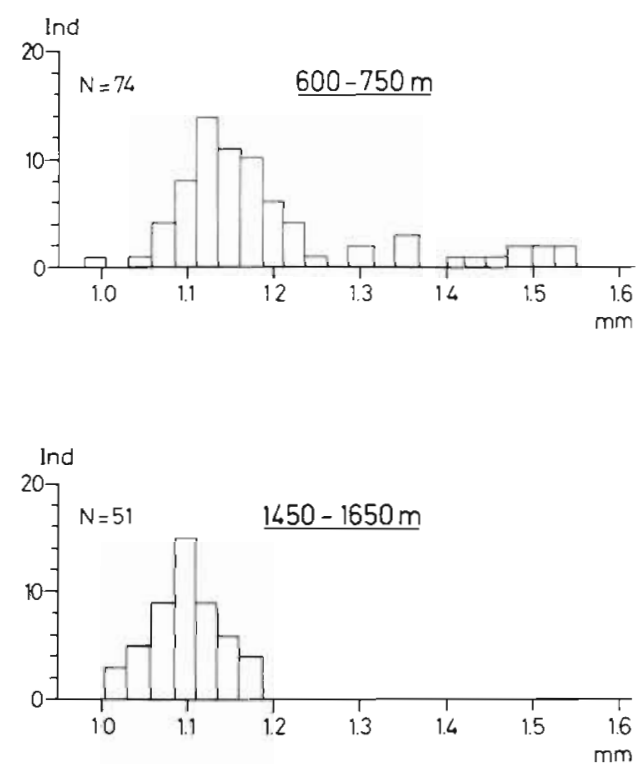

Fig. 2. Macrosetella gracilis. Length-frequency distribution of females from the lower mesopelagic $(600$ to $750 \mathrm{~m})$ and the bathypelagic (1450 to $1650 \mathrm{~m}$ ) zones of the Atlantis II Deep, November 1980
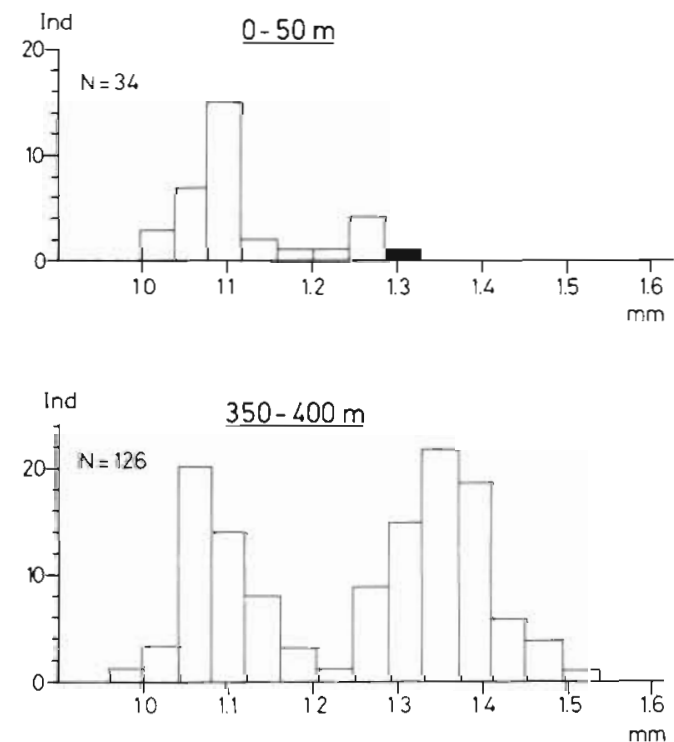

Fig. 3. Macrosetella gracilis. Length-frequency distribution of females from the epipelagic $(0$ to $50 \mathrm{~m}$ ) and upper mesopelagic ( 350 to $400 \mathrm{~m}$ ) zones of the Atlantis II Deep, February 1981 Length of egg-bearing females is shown by the solid column

ples from the upper $50 \mathrm{~m}$ were combined in order to obtain sufficient individuals for the length measurements. A considerable difference in the length-frequency distribution of the females in these 2 populations is apparent (Fig. 4). In the surface zone the range of length variation was the same as that observed during the Trichodesmium bloom in the central Red Sea during
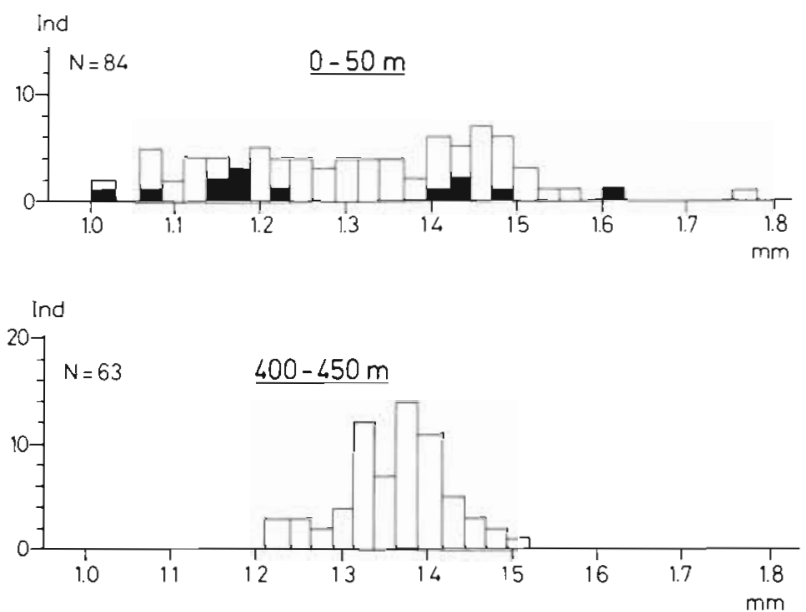

Fig. 4. Macrosetella gracilis. Length-frequency distribution of females from the epipelagic $(0$ to $50 \mathrm{~m})$ and upper mesopelagic $(400$ to $450 \mathrm{~m}$ ) zones of the Kebrit Deep in October 1980. Lengths of egg-bearing females are shown by solid columns

the same season (Fig. 1). However, no pronounced mode showed up in the length distribution for the Kebrit Deep (Fig. 4). In midwater depths, on the other hand, no small females were present, and the length distribution showed a clear mode at about $1.4 \mathrm{~mm}$, which corresponds to that of the group of larger females found in midwater depths at the central station.

\section{DISCUSSION}

The analysis revealed the presence of 2 disctinct size groups, found at different depths, in various regions, and during 2 seasons. The size limit separating the groups varies between 1.2 and $1.3 \mathrm{~mm}$. Thus, the limit of $1.2 \mathrm{~mm}$, arbitrarily chosen to discuss the differences in the vertical distribution patterns of large and small Macrosetella gracilis females (Böttger-Schnack \& Schnack 1989), in fact usually separates 2 distinct size morphs of this species.

Female Macrosetella gracilis less than $1.2 \mathrm{~mm}$ long have not previously been reported from pelagic areas, except once by Tanaka (1960) from the western Indian Ocean. Data on female $M$. gracilis from different regions of the world ocean fall within a length range of $1.2 \mathrm{~mm}$ to $1.6 \mathrm{~mm}$ (Giesbrecht 1892, Kasturirangan 1963, Chen \& Zhang 1974, Boxshall 1979), which corresponds to that of the larger female size group in the Red Sea during the present study. The occurrence of the smaller size group is presumably restricted to the Red Sea and western Indian Ocean. In most of the studies cited above, plankton nets of $0.3 \mathrm{~mm}$ mesh size were used and thus adult $M$. gracilis were not caught quantitatively (Böttger-Schnack 1989). However, all 
reports mention the occurrence of male $M$. gracilis of length 1.0 to $1.2 \mathrm{~mm}$, which corresponds to the range of the smaller size group of females from the Red Sea. Thus it seems unlikely that smaller females were not collected in other parts of the ocean only because of unsuitable sampling methods.

Males Macrosetella gracilis in the Red Sea were between 0.8 and $1.0 \mathrm{~mm}$ in length, which is without exception also smaller than reported from other pelagic areas. Whether they also form distinct size groups corresponding to those of the females has still to be investigated

The occurrence of biomodal length-frequency distributions has been reported for a variety of pelagic marine copepod species. Smaller (winter) and larger (spring) forms can be observed, for example, among Calanus finmarchicus (Marshall et al. 1934). Roe (1972) found 2 size groups among female Nannocalanus minor and female and male Eucalanus attenuatus, which differed according to their depth distribution and vertical migration behaviour. Among cyclopoid copepods, species of the genera Sapphirina (Lehnhofer 1929) and Oncaea (Boxshall 1977) are known to be divided into 2 or more size morphs

The main causes proposed in the literature for the development of different size groups among pelagic copepod species include the influence of seasonal temperature changes and the availability of food (McLaren 1963, Deevey 1964). Higher temperatures or phytoplankton shortages are generally supposed to cause herbivorous copepods to reach shorter lengths (McLaren 1963, Deevey 1964, Sander \& Moore 1983). However, such an effect has not been found among omnivorous or carnivorous cyclopoid species (McLaren 1969, Sander \& Moore 1983). For the harpacticoid copepod Microsetella norvegica there is even an indication that seasonal water temperatures are positively correlated with the body length of adult females (Evans \& Diaz 1878).

The 2 size groups of Macrosetella gracilis females detected in the Red Sea during this study are presumed to have resulted from differences in the availability of blue-green alga Trichodesmium spp. during their development. However, only adults are known definitely to feed on these algae (Roman 1978), while different opinions exist on the feeding of the juvenile stages (Borstad \& Borstad 1977). Size variations based on habitat, such as smaller neritic and larger oceanic forms, as described for Oithona simplex (Nishida \& Marumo 1982), should also be considered as a possible explanation for the existence of distinct size groups among $M$. gracilis females. Morphologically, the 2 size groups were not immediately distinguishable. A more datailed taxonomic study, employing new methods, such as the examination of integumental structures (e.g. Fleminger 1973) might shed light upon the question of whether the groups are size morphs of the same species or 2 closely related Macrosetella species inhabiting the Red Sea.

Acknowledgements. I thank Prof. Dr D. Schnack, who provided critical advice during this study and commented on the manuscript. Dr $\mathrm{H}$. Weikert organized the plankton sampling program in the Red Sea, and Dr C. Heckman improved the English text. The Meseda 3 cruise was funded by the SaudiSudanese Red Sea Joint Commission, Jeddah, and by the Bundesministerium für Forschung und Technologie, Federal Republic of Germany. This study was supported by Deutsche Forschungsgemeinschaft grant Schn 207/7-1 to D. Schnack.

\section{LITERATURE CITED}

Björnberg, T K. S. (1965). Observations on the development and the biology of the Miracidae Dana (Copepoda: Crustacea). Bull. mar. Sci. 15: 512-520

Borstad, G. A., Borstad, L. E. (1977). The Oscillatoria erythraea (Cyanophyta) community of associates. In: Stewart, H. B. Jr (ed.) Cooperative investigations of the Carribbean and adjacent regions. II. FAO Fish. Rep. 200: 51-57

Böttger, R. (1985). Untersuchungen zur Verteilung der klemen Metazoa im Plankton des Roten Meeres, unter besonderer Berücksichtigung cyclopoider und harpacticoider Copepoden. Dissertation, University of Hamburg

Böttger-Schnack, R., Schnack, D. (1989). Vertical distribution and population structure of Macrosetella gracilis (Copepoda: Harpacticoida) in the Red Sea in relation to the occurrence of Oscillatoria (Trichodesmium) spp. (Cyanobacteria). Mar. Ecol. Prog. Ser. 52: 17-31

Boxshall, G. A. (1977). The planktonic copepods of the northeastern Atlantic Ocean: some taxonomic observations on the Oncaeidae (Cyclopoida). Bull. Br. Mus. nat. Hist. (Zool.) 31: 103-155

Boxshall, G. A. (1979). The planktonic copepods of the northeastern Atlantic Ocean: Harpacticoida, Siphonostomatoida and Mormonilloida. Bull. Br. Mus. nat. Hist. (Zool.) 35: 201-264

Carpenter, E. J. (1983). Physiology and ecology of marine planktonic Oscillatoria (Trichodesmium), Review. Mar. Biol. Lett. 4: 69-85

Chen, Q., Zhang, S. (1974). On planktonic copepods of the Yellow Sea and the East China Sea. II. Cyclopoida and Harpacticoida. Studia marina Sinica 9: 1-76 (Chinese)

Deevey, G. B. (1964). Annual variations in length of copepods in the Sargasso Sea off Bermuda. J. mar biol. Ass. U.K. 44: $589-600$

Evans, F., Diaz, W (1978). Microsetella norvegica (Boeck): A direct relationship between seasonal sea temperature and adult size in a planktonic copepod. Crustaceana $34: 313-315$

Fleminger, A. (1973). Pattern, number, variability and taxonomic significance of integumental organs (sensilla and glandular pores) in the genus Eucalanus (Copepoda, Calanoidaj. Fish. Bull. U.S. 71: 965-1010

Giesbrecht, W. (1892). Systematik und Faunistik der pelagischen Copepoden des Golfes von Neapel. Fauna und Flora des Golfes von Neapel und der angrenzenden MeeresAbschnitte XIX: 1-831

Kasturirangan, L. R. (1963). A key for the identification of the more common planktonic copepoda of Indian coastal waters. Indian Nat. Comm. Ocean Res. 2: 1-87 
Lehnhofer, K. (1929). Sapphirina, J. V Thompson 1829, der Deutschen Tiefsee-Expedition. Wiss. Ergebn. dt. TiefseeExp. XXII: 269-347

Marshall, S. M., Nicholls, A. G., Orr, A. P. (1934). On the biology of Calanus finmarchicus. $V$ Seasonal distribution, size, weight and chemical composition in Loch Striven in 1933, and their relation to the phytoplankton. J. mar. biol. Ass. U.K. 19: 793-827

McLaren, I. A. (1963). Effects of temperature on growth of zooplankton, and the adaptive value of vertical migration J. Fish. Res. Bd Can. 20: 685-727

McLaren, I. A. (1969). Population and production ecology of zooplankton in Ogac Lake, a landlocked fjord on Baffin Island. J. Fish. Res. Bd Can. 26: 1485-1559

Nishida, S., Marumo, R. (1982). Vertical distribution of cyclopoid copepods of the family Oithonidae in the Western Pacific and Eastern Indian Ocean. Bull. Plankt. Soc Jpn 29: 99-118

Roe, H. J. S. (1972). The vertical distributions and diurnal

This article was submitted to the editor migrations of calanoid copepods collected on the Sond cruise, 1965. II. Systematic account: Families Calanidae up to and including Aetideidae. J. mar biol. Ass. U.K. 52: $315-343$

Roman. M. R. (1978). Ingestion of the blue-green algae Trichodesmium by the harpacticoid copepod Macrosetella gracilis. Limnol. Oceanogr. 23: 1245-1255

Sander, F., Moore, E. A. (1983). Physioecology of tropical marine copepods. I. Size variations. Crustaceana 44: 83-93

Steedman, H. F. (1976). Examination, sorting and observation fluids. In: Steedman, H. F. (ed.) Zooplankton fixation and preservation. Monogr on oceanogr. methodol. 4. Unesco Press, Paris p. 182-183

Tanaka, O. (1960). Biological results of the Japanese antarctic research expedition. 10. Pelagic Copepoda. Spec. Publ. Seto mar. biol. Lab. 10: 1-95

Weikert, H., John, H.-Ch. (1981). Experiences with a modified Bé multiple opening-closing plankton net. J. Plankton Res. 3: $167-176$

Manuscript received: December 15, 1987 Revised version accepted: November 21, 1988 